\title{
An Analysis on Occupational Differences Regarding Preparation for Retirement: Pension Marketing Approach
}

\author{
Young Sup Park ${ }^{1} \&$ Sang-Bum Park ${ }^{2}$ \\ ${ }^{1}$ Graduate Student, Department of Business Administration, Korea Aerospace University, Korea \\ ${ }^{2}$ Department of Business Administration, Korea Space University, Korea \\ Correspondence: Sang-Bum Park, Professor, Department of Business Administration, Korea Space University, \\ Korea. E-mail: psb@kau.ac.kr
}

Received: October 23, 2018

Accepted: November 21, 2018

Online Published: December 25, 2018

doi:10.5539/ijef.v11n1p140

URL: https://doi.org/10.5539/ijef.v11n1p140

\begin{abstract}
This study examined the perception and preparation of retirement by occupational group and the expected satisfaction of retirement after economic life. This study analyze the retirement not only from policy makers' point of view but also pension marketers' view point. There are different pension schemes for each occupation, and each pension system is in a different situation. Since the pension system is the most basic system of economic life after retirement, it can be assumed that individual economic entities will be in different recognition and preparation states depending on which pension system they belong to. According to the results of the analysis, there are differences in the expected retirement age, expected satisfaction of retirement after economic life, readiness for retirement, and degree of responsibility of the national society for economic life after retirement. The most important factor affecting the satisfaction of the economic life after retirement is the present level of income and recognition and preparation for retirement.
\end{abstract}

Keywords: occupational group, pension system, retirement preparation, economic life satisfaction after retirement, pension marketing

\section{Introduction}

Korea has entered an aged society at a rapid pace that can not be found any earlier. The problem is that situations that have never been experienced before come at a time. In other words, it seems that there is not much preparation for the aged society both nationally and personally.

There are many things that each individual should prepare and prepare for himself or herself in an aged society. Among them, economic contrast is an important means of determining the satisfaction of old age life. Whether or not you are engaged in economic activity in your old age, it is imperative that you can support your own activities. The safest and most important source of income is the pension. Pension is a kind of social insurance that provides long-term income guarantee among the risks of loss of income. Among them, if you face the risk of life due to various income loss in everyday life.

The developed countries are operating a pension system for the sake of social life. As of the end of 2017, there are four public pension schemes for all citizens in Korea. In other words, the public servant pension system for government officials and local public servants, military officers assigned by officers and supporters, military pension schemes for occupational soldiers, private schools for private school teachers and office workers The teacher pension system and the national pension system, which is applied to the general public.

These four pensions have taken different paths, and they are in different situations now, and the prospects for the future are different. The most important part is whether the individual pension system can operate on its own. In the case of the National Pension Scheme, the prospect is not bright. In 2040, the funds will be depleted. In response, the government is continuously introducing and implementing policies to raise pension premiums, reduce payments and delay payment timing. In the case of the military pension and civil servant pension, the state is unable to operate unless it is supported by the tax office. In the case of private pension, the situation is better.

The situation of these individual pensions will have a significant impact on the retirement preparation of the occupations to which they will be subjected. This is because it plays the most fundamental part in the three-tiered 
structure of retirement versus income, which is usually talked about. The triple-structure of income versus retirement, that is, the guarantee of the state, the enterprise and the guarantee of the individual The triple structure of income versus retirement, that is to say, the triple structure of national security, enterprise security and assurance that the individual does by himself.

This situation will also have a considerable effect on the view of retirement of the workers who belong to the individual occupation group and the shape of retirement preparation.

In this study, we survey and analyze the retirement vision, retirement preparation status, responsibility for life after retirement, and satisfaction with life after retirement. The results of this study are as follows: It is expected that it can be usefully used in the future.

\section{Pension Schemes and Prior Research}

\subsection{Announcement of Pension System}

The civil servant pension system was established in August 1949, after the government was established in August 1949, and the National Civil Servant Law was enacted in order to stabilize the retired civil servants and their bereaved family members, Compensation and pension regulations and separate legislation therefor. However, after the founding of the country and the circumstances of the June 25 war and civil servant pension law was promulgated in 1960 , the pension system became effective.

The military pension system was enacted and promulgated in January 1963 under the Act on the Pensions of Soldiers, pursuant to the special legislation of the military pension system.

The public pension system, which has been in existence for more than 10 years with the public servant pension system and the military pension system, has become an issue of income redistribution due to the high growth of the economy and the increase in elderly people due to rapid urbanization, gradual increase of factory workers, The social environment has changed. As a result, the introduction of a new social security system was enacted and the National Welfare Pension Act was enacted and promulgated in December 1973 in accordance with the principle of the National People's Pension System.

However, due to various circumstances, the period of enforcement was reserved, and it was revised by the National Pension Act in December 1986 and enforced in January, 1988. In the beginning, it was planned to include private school staff members in the subject of the National Welfare Pension Act, but due to the suspension of the National Welfare Pension Act, the problem of fraud with private school staff, the balance between national and public teachers under the civil servant pension law, The problem of the education of the school was strongly raised, and in December 1973, the private school staff pension law was enacted and promulgated.

The national pension system has been gradually expanded and implemented according to the application. In January 1988, it was enforced for the first time from a workplace with more than 10 regular employees. From January 1992, it was extended to workplaces with 5 or more employees. In July 1995, the system was extended to residents living in farming and fishing villages and rural areas. In April 1999, the city expanded to include residents in the city, and the era of colonialism began.

\subsection{Precedent Research on Retirement}

Research on retirement has been active in recent years. (2004) analyzed the determinants of retirement in the elderly: the analysis of the factors affecting the retirement decisions of elderly people over 60 years old living in Seoul and Chuncheon, focusing on the analysis of differences between sexes and residences. The authors compared and analyzed the differences in the factors affecting retirement decisions between men and women and urban and rural residents by age and gender. The results of the analysis with the whole data show different results from the analysis of the results with sex, residence area, and various factors. The results of this analysis show that the differentiated policies that are established considering the characteristics of policy beneficiaries such as gender and residence area are more effective than the monotonous policy in the establishment and implementation of various policies related to economic activities and retirement after retirement. . On the other hand, it was confirmed that the subjective perception factor of the proper retirement age and the main responsibility of retirement preparation was a statistically significant variable in the retirement decision of the elderly.

Yoon Kyung (2002) has estimated retirement consumption through target replacement rate, In a study on the retirement financial planning of wage earners in their 20s and 30s Cha Kyung-wook, Park Mi-yeon and Kim Yeon-ju (2008) showed that the expected average retirement age was 56 years, retirement is more interested in 
retirement preparation when occupational or family life is relatively stable, and retirement financial planning is more positive than retirement.

In the study of determinants of economic retirement after the retirement of middle-aged households by marital employment status, Sangwon and Soon-Mi (2010) show the current economic status, financial assets, and gross income as variables influencing the retirement preparation

Baek Eun-young (2011) sought to analyze the present situation of baby boomers' retirement preparation according to the social issue that the retirement of baby boomers, which accounts for $15 \%$. As a result of the analysis, about $79 \%$ of the respondents said that they are preparing to retire in any way, and about $46 \%$ of those using public pension as the main retirement preparation method. Baby boomers were most likely to prepare for retirement in the national pension (38.94\%), followed by accounts and savings (24.39\%), personal pensions $(18.72 \%)$ and real estate $(5.5 \%)$. As a result of examining the factors affecting the retirement preparation type, it was found that the probability of choosing the personal retirement type as the major retirement preparation type is high when the income or education level is high, and the deposit and insurance are actively preparing for retirement through this method It is only a passive choice. The choice of real estate as the main retirement preparation method was related to economic factors such as housing ownership and high income, and practical suggestions for selecting real estate or housing as a major retirement preparation method were provided. In addition, when the national pension was chosen as the main retirement preparation method, policy suggestions were made for their further consideration and their baby's retirement preparation prior to their full retirement.

Kim Ji-kyung (2005) analyzed 1,023 retirees surveyed in the 6th year (2003) of the Korea Labor Panel in the comparison of reasons for gender retirement and income after retirement, and compared the causes of retirement by gender and analyzed the factors affecting income after retirement using the Tobit model. As a result of the analysis, first, $46.9 \%$ of the retirees retire to their own health and they retire earlier than retirement due to retirement. As a result of retirement. The vulnerable groups are highly likely to be vulnerable to the security of systems that can protect them. Second, according to gender, factors affecting retirement income and income after retirement were found to be different. In relation to the characterization of retirees and income after retirement, it is necessary to diagnose problems by gender. An understanding of the approaching female retirees should be preceded. Third, the retirement function of the retirees is shown to be caused by the transfer of private income, and it is expected that the cost of supporting the family, which is currently borne by the family, will gradually be transferred to society due to the change in family culture.

In Jang Ji-yeon and Ho-jeong (2002), the average retirement age of employed workers and the difference in demographic characteristics are expected to increase rapidly in the labor market in the labor market, and the average age of retirement is defined as the 'labor force life table'. As a result, in 2001, a 15-year-old man was expected to retire at age 60.9, and an average of 47.5 years was expected to work for women. These figures are higher than other countries in Korea. The difference in the retirement age by demographic characteristics in Korea shows that the retirement age of the farmer continues to increase and the difference from the non - farmer gradually increases. The retirement age of wage earners increased from 60 years old in 1987 to 5 years old in 10 years and increased to 65 years in 1997, which was followed by a slight decrease after the foreign exchange crisis. The difference between wage workers and non-wage workers was reduced from 12.2 years in 1987 to 9.5 years in 2000 .

Hyunjae Choi, Kim Min Jung (A), Lee Ji Young, and Kim Min Jeong (B) (2012) have high expectations about the ability of households to maintain the necessary level of consumption during the retirement period as the average life expectancy and retirement age increase in the Korean households' (Life Span), which refers to how many years can be spent on retirement funds held by households, to analyze retirement preparedness according to the asset class of Korean households. Data are analyzed by using the data of 6,589 non-retired households under the age of 60 in the National Statistical Office's 2011 household financial survey as main data. As a supplementary data, the National Pension Service Old Age Guarantee Panel (2010), Korea Labor Institute Korea Labor Panel Survey (2010), Investor Protection Fund Investors Survey (2010).

Retirement funds, retirement assets, and economic life are estimated as follows. First, the total amount needed for retirement after the retirement is estimated to be about 820 million won and the median is about 740 million won. The median asset class is about 850 million won, and the average asset class is about 870 million won. The median is about 780 million won and 790 million won respectively. Second, as a result of a hierarchical analysis of retirement assets, the total average of retirement assets 1 plus the lump sum of the financial assets for retirement funds and the pension income of the third floor pension income was 410 million won and the median was 380 million won. The retirement wealth 2 of retirement wealth1 plus the other physical assets other than the 
residence housing was 560 million won and the median was 450 million won. The total household total of retirement wealth 3, which includes the assets of residential housing, is 780 million won, the middle level is 630 million won, and the retirement wealth 2 and 3 are high in the middle and upper wealth classes. Third, the average life expectancy of all households was 69.4 years, assuming that $50 \%$ of financial assets were used as retirement assets and survived to life expectancy. It is analyzed that if the physical assets other than the residential housing are used additionally, it can survive more than two years and if the residential house is pensioned, it can live up to the age of 77 when it is increased by 5.5 years. If all of the financial assets are retired, the economic life span increases by about 2 years compared to the $50 \%$ utilization.

\section{Research Method}

\subsection{Research Problem}

In this study, we hypothesized that the retirement preparation situation will be different depending on the occupational group.

$<$ Hypothesis $1>$ There will be differences in the thoughts and will of retirement by occupation.

$<$ Hypothesis 2> There will be differences in preparation and awareness of retirement by occupation.

$<$ Hypothesis 3> There will be a difference in the level of retirement preparation prepared by each occupation.

$<$ Hypothesis 4> There will be differences in the future retirement life expectancy (satisfaction level) at the level of preparing for retirement by occupation.

In order to test the above hypothesis, we conducted a questionnaire survey. The contents of the questionnaire were divided into basic data part and job inquiry part, followed by retirement thinking and will, retirement preparation and recognition status, The level of preparation, and the expectation of future retirement life. The basic data part consisted of 12 questions. The items of retirement thinking and will part were composed of 9 questions. The retirement recognition and preparation level was composed of 14 questions. .

\subsection{Research Subjects and Data Collection}

The results of this study are summarized as follows. The occupational groups were classified into five groups based on the pension system and wartime traits. In other words, it is the company, the education worker, the general self-employed person, the financial worker, and the professional worker. The occupational groups were classified according to these criteria. Each of these occupations has the following characteristics.

- Employees are eligible for national pension and are entrepreneurs in the workplace.

- The general self-employed is a member of the national pension area, and is a professional group that has to plan on its own.

- Education workers are members of the private pension system. They believe that the private pension funds are still working and that the subscribers are less anxious than other pensioners in terms of supply and demand. They could also be considered to be in a situation similar to those eligible for military pension and civil service pension benefits.

- Financiers are considered to be members of the national pension and occupational pension scheme and the pension-related expert group. They are a group of financial specialists, so they may be different from other occupational groups in their retirement preparations.

- Expert group will belong to self-employed, but in terms of income level, it will belong to high income group when compared with general self-employed, and it is expected that preparation for retirement will be different compared to other groups.

In this study, we collected and distributed 600 questionnaires related to occupational retirement. A total of 541 questionnaires were collected, and 30 items, which were difficult to use for analysis due to insufficient responses, were removed and 511 items were used for analysis. The respondents' occupational group consisted of $29.2 \%$, $16.6 \%, 15.5 \%, 27.4 \%$ and $11.4 \%$, respectively.

\section{Analysis Result}

\subsection{Basic Statistics}

The average household income distribution of monthly survey respondents is as follows. 
Table 1. Monthly household income distribution

\begin{tabular}{lcccc}
\hline Construct & frequency & percent & effective percent & cumulative percent \\
\hline Below 1.5 million won & 292 & 57.1 & 57.1 & 57.1 \\
1.5 million - 3 million won & 132 & 25.8 & 25.8 & 83.0 \\
3 million won - 5 million won & 69 & 13.5 & 13.5 & 96.5 \\
5 million won - 10 million won & 12 & 2.3 & 2.3 & 98.8 \\
above 10 million won & 6 & 1.2 & 1.2 & 100 \\
sum & 511 & 100 & 100 & \\
\hline
\end{tabular}

On the other hand, the average income distribution of the respondents is as follows.

Table 2. Average income distribution by occupation

\begin{tabular}{cccc}
\hline & average & $\mathrm{N}$ & standard deviation \\
\hline employed & 2.92 & 149 & .874 \\
education & 3.05 & 85 & .844 \\
self-employment & 3.25 & 79 & .993 \\
financial business & 3.01 & 140 & 1.014 \\
professional & 3.17 & 58 & .901 \\
sum & 3.05 & 511 & .935 \\
\hline
\end{tabular}

As can be seen in the above table, average income by occupation is the highest in self-employment, followed by professionals, followed by education, finance, and office workers.

The level of net worth by respondents is as follows. However, in the case of net assets, there is a possibility that other factors such as inheritance or inheritance are working.

Table 3. Net asset level

\begin{tabular}{ccccc}
\hline & frequency & percent & effective percent & cumulative percent \\
\hline Less than 200 million won & 29 & 57.1 & 57.1 & 57.1 \\
200 - 500 million won & 132 & 25.8 & 25.8 & 83.0 \\
500 million - 1000 million won & 69 & 13.5 & 13.5 & 96.5 \\
1000 - 2000 million won & 12 & 2.3 & 2.3 & 98.8 \\
above 2000 million won & 6 & 1.2 & 1.2 & 100.0 \\
sum & 511 & 100.0 & 100.0 & \\
\hline
\end{tabular}

On the other hand, $64.4 \%$ of the respondents answered that they were not in favor of financial design experts. These figures are low compared to those of other developed countries, for example, more than $50 \%$ of US financial consumers seek expert advice Eric T. Bradlow et al., Kim Hee jung, "Wharton School, published by Power Marketing to power financial consumers", FPBOOKS, 2012.

Table 4. Whether to consult financial experts

\begin{tabular}{ccccc}
\hline & frequency & percent & effective percent & cumulative percent \\
\hline Assisted reception & 169 & 33.1 & 33.1 & 33.1 \\
No assistance & 329 & 64.4 & 64.4 & 97.5 \\
No answer & 13 & 2.5 & 2.5 & 100.0 \\
sum & 511 & 100 & 100 & \\
\hline
\end{tabular}

Cross-sectional analysis was conducted to examine income differences among the occupational groups. As a result, the ratio of income earning over KRW 10 million was in the order of self-employed, financial, and professional workers. In the case of earning less than KRW 1.5 million, the lowest rate was employee, professional worker, finance, education and general self-employed. The crossover analysis results are summarized in the following table, respectively. 
Table 5. Cross-sectional analysis of occupations and income

\begin{tabular}{|c|c|c|c|c|c|c|c|c|}
\hline & & & \multicolumn{5}{|c|}{ Income } & \multirow[b]{2}{*}{ total } \\
\hline & & & employed & education & Self-employed & Financial business & professional & \\
\hline \multirow{24}{*}{ Occupation } & \multirow[t]{4}{*}{ Employed } & Freqency & 10 & 30 & 74 & 32 & 3 & 149 \\
\hline & & \%ofSQ3 & 6.7 & 20.1 & 49.7 & 21.5 & 2.0 & 100 \\
\hline & & \&ofSQ6 & 45.5 & 25.6 & 34.1 & 25.4 & 10.3 & 29.2 \\
\hline & & Total $\%$ & 2.0 & 5.9 & 14.5 & 6.3 & 6 & 29.2 \\
\hline & \multirow[t]{4}{*}{ Education } & Freqency & 2 & 21 & 34 & 27 & 1 & 85 \\
\hline & & \%ofSQ3 & 2.4 & 24.7 & 40.0 & 31.8 & 1.2 & 100 \\
\hline & & \%ofSQ6 & 9.1 & 17.9 & 15.7 & 21.4 & 3.4 & 16.6 \\
\hline & & Total & .4 & 4.1 & 6.7 & 5.3 & .2 & 16.6 \\
\hline & \multirow[t]{4}{*}{ Self-employed } & Freqency & 1 & 18 & 30 & 20 & 10 & 79 \\
\hline & & \%ofSQ3 & 1.3 & 22.8 & 38.0 & 25.3 & 12.7 & 100 \\
\hline & & \%ofSQ6 & 4.5 & 15.4 & 13.8 & 15.9 & 34.5 & 15.5 \\
\hline & & Total & .2 & 3.5 & 5.9 & 3.9 & 2.0 & 15.5 \\
\hline & \multirow{4}{*}{$\begin{array}{l}\text { Financial } \\
\text { business }\end{array}$} & Freqency & 6 & 42 & 48 & 33 & 11 & 140 \\
\hline & & \%ofSQ3 & 4.3 & 30.0 & 34.3 & 23.6 & 7.9 & 100 \\
\hline & & \%ofSQ6 & 27.3 & 35.9 & 22.1 & 26.2 & 37.9 & 27.4 \\
\hline & & Total & 1.2 & 8.2 & 9.4 & 6.5 & 2.2 & 27.4 \\
\hline & \multirow[t]{5}{*}{ Professional } & Freqency & 3 & 6 & 31 & 14 & 4 & 58 \\
\hline & & \%ofSQ3 & 5.2 & 10.3 & 53.4 & 24.1 & 6.9 & 100 \\
\hline & & \%ofSQ6 & 13.6 & 5.1 & 14.3 & 11.1 & 13.8 & 11.4 \\
\hline & & Total & .6 & 1.2 & 6.1 & 2.7 & .8 & 11.4 \\
\hline & & Freqency & 22 & 117 & 217 & 126 & 29 & 511 \\
\hline & \multirow[t]{3}{*}{ total } & \%ofSQ3 & 4.3 & 22.9 & 42.5 & 24.7 & 5.7 & 100 \\
\hline & & \%ofSQ6 & 100 & 100 & 100 & 100 & 100 & 100 \\
\hline & & Total & 4.3 & 22.9 & 42.5 & 24.7 & 5.7 & 100 \\
\hline
\end{tabular}

A chi-squared analysis was performed to analyze the characteristics and the relationship between variables. The results are as follows.

Table 6. Chi-square test of crossover

\begin{tabular}{lccc}
\hline & value & Degree of freedom & Probability of asymptotic significance (two-tailed test) \\
\hline Pearson Chi-square & $35.523(\mathrm{a})$ & 16 & .003 \\
likelihood ratio & 37.371 & 16 & .002 \\
Linear vs. linear combination & 2.443 & 1 & .118 \\
Effective cases & 511 & & \\
\hline
\end{tabular}

As can be seen in the table above, the difference in income by occupation is significant at $1 \%$ level.

On the other hand, the expected retirement age by occupation group is as follows.

Table 7. Estimated retirement age by occupation

\begin{tabular}{cccccccccc}
\hline & $\mathrm{N}$ & average & $\begin{array}{c}\text { standard } \\
\text { deviation }\end{array}$ & \multicolumn{2}{l}{$\begin{array}{l}\text { standard } \\
\text { error }\end{array}$} & \multicolumn{2}{c}{$\begin{array}{c}\text { 95\% confidence interval for the mean } \\
\text { lower limit }\end{array}$} & minimum & maximum \\
\hline employee & 149 & 2.61 & 1.038 & .085 & 2.44 & 2.78 & 1 & 5 \\
education & 85 & 2.82 & .789 & .086 & 2.65 & 2.99 & 1 & 5 \\
self-employment & 79 & 3.34 & .815 & .092 & 3.16 & 3.52 & 1 & 5 \\
financial business & 140 & 2.82 & 1.088 & .092 & 2.64 & 3.00 & 1 & 6 \\
professional & 58 & 2.93 & .87 & .115 & 2.70 & 3.16 & 1 & 6 \\
sum & 511 & 2.85 & .990 & .044 & 2.77 & 2.94 & 1 & 6 \\
\hline
\end{tabular}

There is a difference in the retirement time according to the occupation group, and it is analyzed that the self-employed is likely to retire at the latest time, followed by the professional worker, the education sector and the financial sector, and the office worker wants to retire as soon as possible. The results are statistically significant at the $1 \%$ level as summarized in the following table. 
Table 8. Analysis of variance

\begin{tabular}{lccccc}
\hline & Sum of squares & Degree of freedom & Mean square & F & Probability of significance \\
\hline between groups & 28.184 & 4 & 7.046 & 7.557 & .000 \\
within group & 471.808 & 506 & .932 & & \\
sum & 499.992 & 510 & & & \\
\hline
\end{tabular}

In addition, the results of this study were analyzed by covariance analysis (ANOCOVA) with age as an exogenous variable. The results are shown in Tables 9 and 10 below.

Table 9. Covariance analysis result

\begin{tabular}{lccccc}
\hline source & Type III sum of squares & Degree of freedom & Mean square & F & Probability of significance \\
\hline modified model & $34.727(\mathrm{a})$ & 5 & 6.945 & 7.539 & .000 \\
intercept & 85.691 & 1 & 85.691 & 93.010 & .000 \\
age & 6.542 & 1 & 6.542 & 7.101 & .008 \\
occupation & 22.886 & 4 & 5.721 & 6.210 & .000 \\
error & 465.265 & 505 & .921 & & \\
sum & 4660.000 & 511 & & & \\
modified sum & 499.992 & 510 & & & \\
\hline
\end{tabular}

Table 10. Parameter estimate

\begin{tabular}{|c|c|c|c|c|c|c|}
\hline \multirow[t]{2}{*}{ parameter } & \multirow[t]{2}{*}{ beta } & \multirow[t]{2}{*}{ standard error } & \multirow[t]{2}{*}{$\mathrm{t}$} & \multirow{2}{*}{$\begin{array}{c}\text { Probability of } \\
\text { significance }\end{array}$} & \multicolumn{2}{|c|}{$95 \%$ confidence interval } \\
\hline & & & & & Lower limit & Upper limit \\
\hline intercept & 2.287 & .273 & 8.386 & .000 & 1.751 & 2.822 \\
\hline age & .014 & .005 & 2.665 & .008 & .004 & .025 \\
\hline [SQ3=1] employee & -.260 & .150 & -1.732 & .084 & -.555 & .035 \\
\hline [SQ3=2] education & -.100 & .164 & -.609 & .543 & -.421 & .222 \\
\hline [SQ3=3] self-employment & .409 & .166 & 2.462 & .014 & .083 & .735 \\
\hline [SQ3=4] financial business & -.054 & .151 & -.354 & .724 & -.351 & .244 \\
\hline [SQ3=5] professional & 0 (a) & & & & & \\
\hline
\end{tabular}

Age has a significant effect, and differences by occupation are still significant.

\subsection{Hypothesis Verification Result}

\subsubsection{Satisfaction with Retirement Benefits}

Analysis of satisfaction with pension benefits after retirement under current circumstances. ANOCOVA (ANOCOVA), which analyzes the effects of pension benefits on the assumption that pension benefit will vary depending on the occupational group but may be affected by age and income level, And the results are summarized in the following table.

1) Satisfaction with pension benefits

Table 11. Satisfaction with pension benefits

\begin{tabular}{|c|c|c|c|c|c|c|c|c|}
\hline & \multirow[t]{2}{*}{$\mathrm{N}$} & \multirow[t]{2}{*}{ average } & \multirow{2}{*}{$\begin{array}{c}\text { Standard } \\
\text { Deviation }\end{array}$} & \multirow{2}{*}{$\begin{array}{c}\text { Standard } \\
\text { error }\end{array}$} & \multicolumn{2}{|c|}{$95 \%$ confidence interval for the mean } & \multirow[t]{2}{*}{ Minimum } & \multirow[t]{2}{*}{ Maximum } \\
\hline & & & & & Lower limit & Upper limit & & \\
\hline employed & 149 & 2.81 & .665 & .054 & 2.70 & 2.91 & 1 & 4 \\
\hline education & 85 & 3.08 & .676 & .073 & 2.94 & 3.23 & 1 & 5 \\
\hline self-employment & 79 & 2.95 & .932 & .105 & 2.74 & 3.16 & 1 & 5 \\
\hline financial business & 140 & 2.96 & .666 & .056 & 2.85 & 3.07 & 1 & 5 \\
\hline profession & 58 & 2.88 & .774 & .102 & 2.68 & 3.08 & 1 & 5 \\
\hline sum & 511 & 2.92 & .730 & .032 & 2.86 & 2.99 & 1 & 5 \\
\hline
\end{tabular}

On average, pension benefits are the highest in education, followed by financial providers, self-employed, professionals, and employees. These results are statistically significant at the $10 \%$ level as summarized in the following table. 
Table 12. Analysis of variance

\begin{tabular}{cccccc}
\hline & Sum of squares & Degree of freedom & Mean square & F & Probability of significance \\
\hline between groups & 4.549 & 4 & 1.137 & 2.151 & .073 \\
within groups & 267.475 & 506 & .529 & & \\
sum & 272.023 & 510 & & & \\
\hline
\end{tabular}

2) Pension benefit rate considering income level and age

On the other hand, the covariance analysis using the monthly average household income as an exogenous variable was conducted on the assumption that the pension benefit level may be related to income. The results are shown in Tables 13 and 14 below.

Table 13. Pension benefit satisfaction covariance analysis result

\begin{tabular}{lccccc}
\hline construct & Type III sum of squares & Degree of freedom & Mean square & F & Probability of significance \\
\hline modified model & $17.164(a)$ & 5 & 3.433 & 7.478 & .000 \\
intercept & 263.047 & 1 & 263.047 & 573.031 & .000 \\
age & 12.298 & 1 & 12.298 & 26.791 & .000 \\
occupation & 4.259 & 4 & 1.065 & 2.319 & .056 \\
error & 231.818 & 505 & .459 & & \\
sum & 4866.000 & 511 & & & \\
modified sum & 248.982 & 510 & & & \\
\hline
\end{tabular}

Table 14. Parameter estimate

\begin{tabular}{|c|c|c|c|c|c|c|}
\hline \multirow[t]{2}{*}{ parameter } & \multirow[t]{2}{*}{ beta } & \multirow[t]{2}{*}{ standard error } & \multirow[t]{2}{*}{$\mathrm{t}$} & \multirow{2}{*}{$\begin{array}{c}\text { Probability of } \\
\text { significance }\end{array}$} & \multicolumn{2}{|c|}{$95 \%$ confidence interval } \\
\hline & & & & & Lower limit & Upper limit \\
\hline intercept & 2.435 & .136 & 17.930 & .000 & 2.168 & 2.701 \\
\hline income & .167 & .032 & 5.176 & .000 & .104 & .231 \\
\hline [SQ3=1] employee & -.037 & .105 & -.354 & .723 & -.244 & .169 \\
\hline$[\mathrm{SQ} 3=2]$ education & .232 & .115 & 2.009 & .045 & .005 & .459 \\
\hline [SQ3=3] self-employment & .059 & .117 & .503 & .615 & -.171 & .289 \\
\hline [SQ3=4] financial business & .091 & .106 & .856 & .392 & -.117 & .299 \\
\hline$[\mathrm{SQ} 3=5]$ profession & $0(a)$ & & & & & \\
\hline
\end{tabular}

Monthly household income has a significant effect, and the difference in satisfaction by occupation is also significant.

On the other hand, the analysis of covariance (ANOCOVA) was conducted to analyze the satisfaction of retirement pension on the assumption that the satisfaction level of retirement may be different even in the same occupation group according to age and the result is not statistically significant.

\subsubsection{National Social Responsibility for Elderly Support}

Under the present circumstances, we analyzed the view of the degree of national social responsibility for the elderly support. The assumption of this responsibility will depend on the occupational group and also on the assumption that it will be influenced by age and income level. Analysis of covariance (ANOCOVA) was performed and the results are summarized in Tables 15 and 16 below.

1) Social responsibility of the elderly

Table 15. Social responsibility of the elderly

\begin{tabular}{|c|c|c|c|c|c|c|c|c|}
\hline & \multirow[t]{2}{*}{$\mathrm{N}$} & \multirow[t]{2}{*}{ average } & \multirow{2}{*}{$\begin{array}{l}\text { standard } \\
\text { deviation }\end{array}$} & \multirow{2}{*}{$\begin{array}{l}\text { standard } \\
\text { error }\end{array}$} & \multicolumn{2}{|c|}{$95 \%$ confidence interval for the mean } & \multirow[t]{2}{*}{ Minimum } & \multirow[t]{2}{*}{ Maximum } \\
\hline & & & & & Lower limit & Upper limit & & \\
\hline employee & 147 & 3.47 & 1.016 & .084 & 3.30 & 3.63 & 1 & 5 \\
\hline Education & 84 & 3.64 & .965 & .105 & 3.43 & 3.85 & 1 & 5 \\
\hline self-employment & 78 & 2.94 & 1.109 & .126 & 2.69 & 3.19 & 1 & 5 \\
\hline Financial business & 139 & 3.28 & 1.097 & .093 & 3.10 & 3.46 & 1 & 5 \\
\hline Professional & 58 & 2.98 & 1.132 & .149 & 2.69 & 3.28 & 1 & 5 \\
\hline sum & 506 & 3.31 & 1.083 & .048 & 3.21 & 3.40 & 1 & 5 \\
\hline
\end{tabular}


Table 16. Analysis of variance

\begin{tabular}{lccccc}
\hline & Sum of squares & Degree of freedom & Mean square & F & Probability of significance \\
\hline within group & 30.287 & 4 & 7.572 & 6.755 & .000 \\
between groups & 561.618 & 501 & 1.121 & & \\
sum & 591.905 & 505 & & & \\
\hline
\end{tabular}

Supporting the aging society aging society The answer to the question of the degree of social responsibility is the employee of the education industry, followed by the office worker, financial industry, professional worker, and self-employed person. Rather, it seems to be related to the situation that self-employed people think that they should be responsible for their old age because they think they have the lowest responsibility. These differences are statistically significant at the $1 \%$ level.

2) Social responsibility of the elderly in consideration of income and age

In terms of the extent of this responsibility, both covariance analysis with income and age as exogenous variables show statistically insignificant results.

\subsubsection{Satisfaction with Economic Life after Retirement (Expected))}

The analysis of the satisfaction with the economic life after retirement under the current circumstances and the analysis of the covariance (ANOCOVA) which can analyze the effect of economic life satisfaction on the assumption that it will be affected by age and income level, And the results are summarized in the following table.

1) Satisfaction with economic life after retirement (Expected)

Table 17. Satisfaction with economic life after retirement (Expected)

\begin{tabular}{|c|c|c|c|c|c|c|c|c|}
\hline & \multirow[t]{2}{*}{$\mathrm{N}$} & \multirow[t]{2}{*}{ average } & \multirow{2}{*}{$\begin{array}{l}\text { Stand. } \\
\text { deviation }\end{array}$} & \multirow{2}{*}{$\begin{array}{l}\text { Stand. } \\
\text { error }\end{array}$} & \multicolumn{2}{|c|}{$95 \%$ confidence interval for the mean } & \multirow[t]{2}{*}{ minimum } & \multirow[t]{2}{*}{ maximum } \\
\hline & & & & & lower limit & upper limit & & \\
\hline employee & 149 & 2.89 & .703 & .058 & 2.77 & 3.00 & 1 & 5 \\
\hline education & 85 & 3.18 & .676 & .073 & 3.03 & 3.32 & 1 & 5 \\
\hline self-employment & 79 & 3.04 & .839 & .094 & 2.85 & 3.23 & 1 & 5 \\
\hline financial business & 140 & 3.03 & .611 & .052 & 2.93 & 3.13 & 2 & 5 \\
\hline professional & 58 & 2.97 & .674 & .089 & 2.79 & 3.14 & 1 & 5 \\
\hline sum & 511 & 3.01 & .699 & .031 & 2.95 & 3.07 & 1 & 5 \\
\hline
\end{tabular}

Satisfaction with economic life after retirement (education) is highest in education, followed by general self-employment, financial business, professional worker, and office worker. These results are statistically significant at the $5 \%$ level.

Table 18. Analysis of variance

\begin{tabular}{lccccc}
\hline & Sum of square & Degree of freedom & Mean square & F & Probability of significance \\
\hline between groups & 4.866 & 4 & 1.217 & 2.522 & .040 \\
within group & 244.116 & 506 & .482 & & \\
sum & 248.982 & 510 & & & \\
\hline
\end{tabular}

On the other hand, ANOCOVA was used to analyze the covariance of monthly average income as an exogenous variable. The results are as follows.

Table 19. Covariance analysis result

\begin{tabular}{lccccc}
\hline construct & Type III sum of squares & Degree of freedom & Mean square & F & Probability of significance \\
\hline modified model & $17.164(a)$ & 5 & 3.433 & 7.478 & .000 \\
intercept & 263.047 & 1 & 263.047 & 573.031 & .000 \\
SQ6 & 12.298 & 1 & 12.298 & 26.791 & .000 \\
SQ3 & 4.259 & 4 & 1.065 & 2.319 & .056 \\
error & 231.818 & 505 & .459 & & \\
sum & 4866.000 & 511 & & & \\
modified sum & 248.982 & 510 & & & \\
\hline
\end{tabular}


As shown in the above table, statistically, $1 \%$ level is significant.

Table 20. Parameter estimate

\begin{tabular}{|c|c|c|c|c|c|c|}
\hline \multirow[t]{2}{*}{ parameter } & \multirow[t]{2}{*}{ beta } & \multirow[t]{2}{*}{ standard error } & \multirow[t]{2}{*}{$\mathrm{t}$} & \multirow[t]{2}{*}{ Probability of significance } & \multicolumn{2}{|c|}{$95 \%$ confidence interval } \\
\hline & & & & & Upper limit & Lower limi \\
\hline intercept & 2.435 & .136 & 17.930 & .000 & 2.168 & 2.701 \\
\hline SQ6 & .167 & .032 & 5.176 & .000 & .104 & .231 \\
\hline$[\mathrm{SQ} 3=1]$ & -.037 & .105 & -.354 & .723 & -.244 & .169 \\
\hline$[\mathrm{SQ} 3=2]$ & .232 & .115 & 2.009 & .045 & .005 & .459 \\
\hline [SQ3=3] & .059 & .117 & .503 & .615 & -.171 & .289 \\
\hline [SQ3=4] & .091 & .106 & .856 & .392 & -.117 & .299 \\
\hline$[\mathrm{SQ} 3=5]$ & $0(\mathrm{a})$ & & & & & \\
\hline
\end{tabular}

On the other hand, the results of covariance analysis using age as an exogenous variable are not significant.

\subsubsection{Tax Rate Increase for Higher Pension Amount after Retirement}

There is no statistically significant difference in the number of surveys for raising the current tax rate and paying out the financial resources after retirement for the purpose of preparing for economic life after retirement.

\subsubsection{Discriminant Analysis}

A stepwise discriminant analysis was conducted to identify factors affecting satisfaction with economic life after retirement.

Discriminant analysis is used to determine the degree of discrimination of the subject of analysis or to grasp the plate change of the discriminant variable or to predict the group of the subject.

In order to analyze the factors affecting the satisfaction of the economic life after retirement, the economic life satisfaction after retirement is a dependent variable, and it is estimated that the occupational group, monthly average household disinfection, estimated retirement period, whether to worry about life after retirement / The results of this analysis are shown in Tables 21 and 22 below.

Table 21. Discriminant analysis result

\begin{tabular}{|c|c|c|c|c|c|c|c|c|c|}
\hline \multirow[t]{3}{*}{ step } & \multirow[t]{3}{*}{ Entered } & \multicolumn{8}{|c|}{ Wilks's Lambda } \\
\hline & & \multirow[t]{2}{*}{ statistic } & \multirow[t]{2}{*}{ df1 } & \multirow[t]{2}{*}{ df2 } & \multirow[t]{2}{*}{ df3 } & \multicolumn{4}{|c|}{ Exact $F$} \\
\hline & & & & & & statistic & df1 & df2 & Probability of significance \\
\hline 1 & income & .940 & 1 & 4 & 506 & 8.135 & 4 & 506.00 & .000 \\
\hline 2 & Retirement worries and plans & .902 & 2 & 4 & 506.00 & 6.693 & 8 & 1010.0 & .000 \\
\hline
\end{tabular}

Table 22. Wilks's Lambda

\begin{tabular}{ccccccccccc}
\hline \multirow{2}{*}{ step } & variable No. & Lambda & df1 & df2 & df3 & \multicolumn{4}{c}{ Exact F } \\
\cline { 7 - 11 } & & & & & & & statistic & df1 & df2 & Probability of significance \\
\hline 1 & 1 & .940 & 1 & 4 & 506 & 8.135 & 4 & 506.000 & .000 \\
2 & 2 & .902 & 2 & 4 & 506 & 6.693 & 8 & 1010.00 & .000 \\
\hline
\end{tabular}

After retirement, the most important variable related to economic life is the present income and the attitude to prepare for life after retirement. Of course, there is a statistically significant difference in earnings between jobs.

\section{Conclusion}

There are serious problems that we have now, but one of the most urgent and important problems is the preparation for life after retirement. Baby boomers have already begun retiring, and the voice of trial and error is high. It is the calm and planned preparation that determines the life after retirement, especially the economic aspect, which is the responsibility of both the company and the individual as well as the state and society. Often refers to the three axes that will bear the economy after retirement: the state, the enterprise (workplace), and the axis that the individual must build. One of the most important axes is pensions. The pension system, which is the main pillar of the national society, is important not only for social security but also for economic and social justice. 
In this study, we surveyed and analyzed the occupational thoughts and actual conditions of the pension system in Korea, which are currently operating under different systems. As a result, different perspectives, readiness, and anticipation are emerging for each occupational group, and it cannot be said that coping is necessary.

According to the results of the analysis, there is a difference in the average income by occupation. Average income by occupation is in the order of self-employment, profession, education, finance, and office worker. The retirement age is expected to be the earliest time for an employee, followed by education, finance, professional workers, and general self - employed. As expected, the satisfaction rate of pension benefits after retirement is the highest in the education sector, followed by the financiers, self-employed, professionals, and office workers. When asked about the degree of national social responsibility for the elderly support in an aged society, the education worker is the most responsible person, financial business, professional worker and self-employed person. Satisfaction with economic life after retirement is the highest in education, followed by general self-employed, finance, professional workers.

Factors affecting the satisfaction of economic life after retirement The most influential factors are income, and whether or not they have retirement - related worries and plans. It is reasonable to assume that the current income will affect the economic life after retirement. The fact that the perception of life after retirement and the preparation for it are very important factors is in line with other researches. It would be desirable to awaken this situation and encourage them to prepare for life after retirement as early as possible. In order to be positive and positive about the perception of retirement, it should be promoted and education and training should be carried out if necessary.

\section{References}

Bae, E. Y. (2011). Baby Boomer's retirement preparation and determinants of the type of preparation. Social Security Research, 27(2), 357-383.

Cha, G. W., Park, M. Y., \& Kim, Y. J. (2008), A Study on the Retirement Finance Design of Wage Earners in the 20s and 30s. Journal of the Korean Home Economics Management Association, 26(1), 149-163.

Choi, H. J., Kim, M. J., Lee, J. J., \& Kim, M. J. (2012). Measuring the retirement preparedness of Korean households by estimating economic life. Financial Planning Review, 5(4), 47-71.

Eric, T. B. (2002). Power Marketing, which drives the financial consumers that the Wharton School has released. FPBOOKS.

Jang, J. Y., \& Ho, J. H. (2002). Changes in the Retirement Age and Difference in Population Characteristics of Employed Persons. Korea Labor Institute, 2(2), 1-21.

Kim, J. K. (2005). Gender Retirement Reason and Retirement Income Comparison. Social Security Research, 21(2), 55-76.

Kwan, S., \& Hwang, G. S. (2004). A Study on the Determinants of Retirement in the Elderly: Focusing on the Difference of Sex and Place of residence. Korea Geriatrics, 24(3), 69-90.

Son, W., \& Kim, S. M. (2010). A study on the determinants of economic retirement after the retirement of middle-aged households: Focusing on the status of married couple employment. Korea Home Management Association, 2010 Spring Conference, p. 349.

Yeo, Y. K. (2002). Estimation of Retirement Consumption through Target Income Replacement Rates. Journal of the Korea Household Association, 40(3), 83-97.

\section{Copyrights}

Copyright for this article is retained by the author(s), with first publication rights granted to the journal.

This is an open-access article distributed under the terms and conditions of the Creative Commons Attribution license (http://creativecommons.org/licenses/by/4.0/). 